\title{
The economic impacts of woodchip storage optimization: Reducing material and energy loss during transportation and storage
}

\author{
by Torben Jensen ${ }^{1}$
}

\begin{abstract}
The use of woody biomass for domestic bioenergy provides many benefits and opportunities, but also presents a challenge regarding the supply chain required for maintaining the high quality feedstock for sustained bioenergy production. This article focuses on one aspect of that supply chain - woodchip storage. To encourage the establishment of a bioenergy market and to help ensure a safe and stable fuel source, Suzanne Wetzel and Christopher Helmeste from the Canadian Forest Service, Canadian Wood Fibre Centre (CFS/CWFC) and collaborators contributed their scientific expertise to the development of a solid biofuels guide based on existing national standards from the Canadian Standard Association's (CSA). This paper explores the potential economic impacts for bioenergy producers of implementing the CSA guidelines. These impacts include reducing material and energy loss during transportation and storage. Potential benefits were determined by cost-benefit analysis. The results of this economic impact study have significant potential implications for bioenergy producers, including the integration of economic considerations in the development of policies for biomass feedstock optimization for the Canadian bioenergy industry.
\end{abstract}

Keywords: solid biofuels guide; economic impacts

\section{RÉSUMÉ}

Il y a plusieurs avantages à utiliser la biomasse forestière comme source de bioénergie domestique; toutefois, cette technologie pose des défis importants pour le maintien d'une chaîne logistique de haute qualité nécessaire à la production continue de bioénergie. Cet article s'intéresse surtout à un des aspects de cette chaîne logistique, soit l'entreposage des copeaux. En vue de favoriser la création d'un marché de la bioénergie et un approvisionnement sûr et stable en combustible, Suzanne Wetzel et Christopher Helmeste rattachés au Centre canadien sur la fibre de bois au Service canadien des forêts (SCF/(CCFB) et leurs collaborateurs ont mis en commun leur expertise scientifique pour créer un guide sur les biocarburants solides fondé sur les normes canadiennes actuelles de la CSA (Canadian Standard Association). Cet article analyse les répercussions économiques que pourrait avoir la mise en œuvre de ces lignes directrices de la CSA pour les producteurs de bioénergie. Parmi celles-ci on note entre autres une diminution des pertes d'énergie et de matière liées au transport et à l'entreposage. Les avantages escomptés ont été estimés à partir d'une analyse coût-avantage. Les résultats de cette étude d'impact économique risquent d'avoir des implications importantes pour les producteurs de bioénergie, notamment la prise en compte de facteurs économiques dans l'élaboration de politiques pour l'optimisation de la fourniture de biomasse à l'industrie canadienne de la bioénergie.

Mots-clés: guide des biocarburants solides; impacts économiques

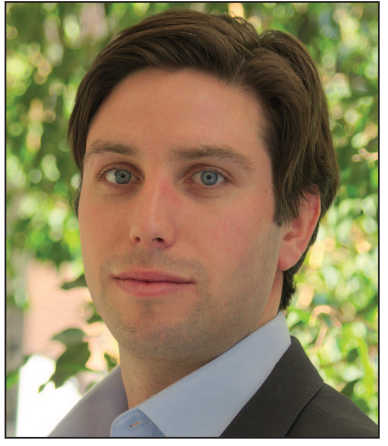

Torben Jensen

\section{Introduction}

The use of woody biomass for domestic bioenergy provides many benefits and opportunities. Bioenergy is currently one of the only sources of baseload (24/7) renewable energy for which supply can be ramped up or down as needed. It is helping Canada achieve its international climate agreements, and it provides a cleaner alternative energy source for remote and indige-

nous communities. Globally, bioenergy contributes more to heat generation than electricity, accounting for $9 \%$ of the world's heat energy. Between 2005 and 2015, Canadian bioenergy electricity generation increased by $54 \%$, now accounting for $2 \%$ of the country's total energy generation, up from $0.7 \%$ in 2005 (Natural Resources Canada 2020).

\section{Outcomes}

- Canadian bioenergy facilities produce enough energy to heat over 42,000 single detached homes, consuming \$28 $\mathrm{M}$ of biomass annually;

- Optimization of feedstock storage and transportation addresses critical quality and safety issues for a more stable and predictable supply chain with less economic loss;

- Reducing decomposition can result in material savings of more than $\$ 2$ million for bioenergy producers annually (Fig. 1).

${ }^{1}$ Canadian Forest Service, 580 Booth St., Ottawa, Ontario K1A 0E4, Canada, email: Torben.jensen@nrcan-rncan.gc.ca 


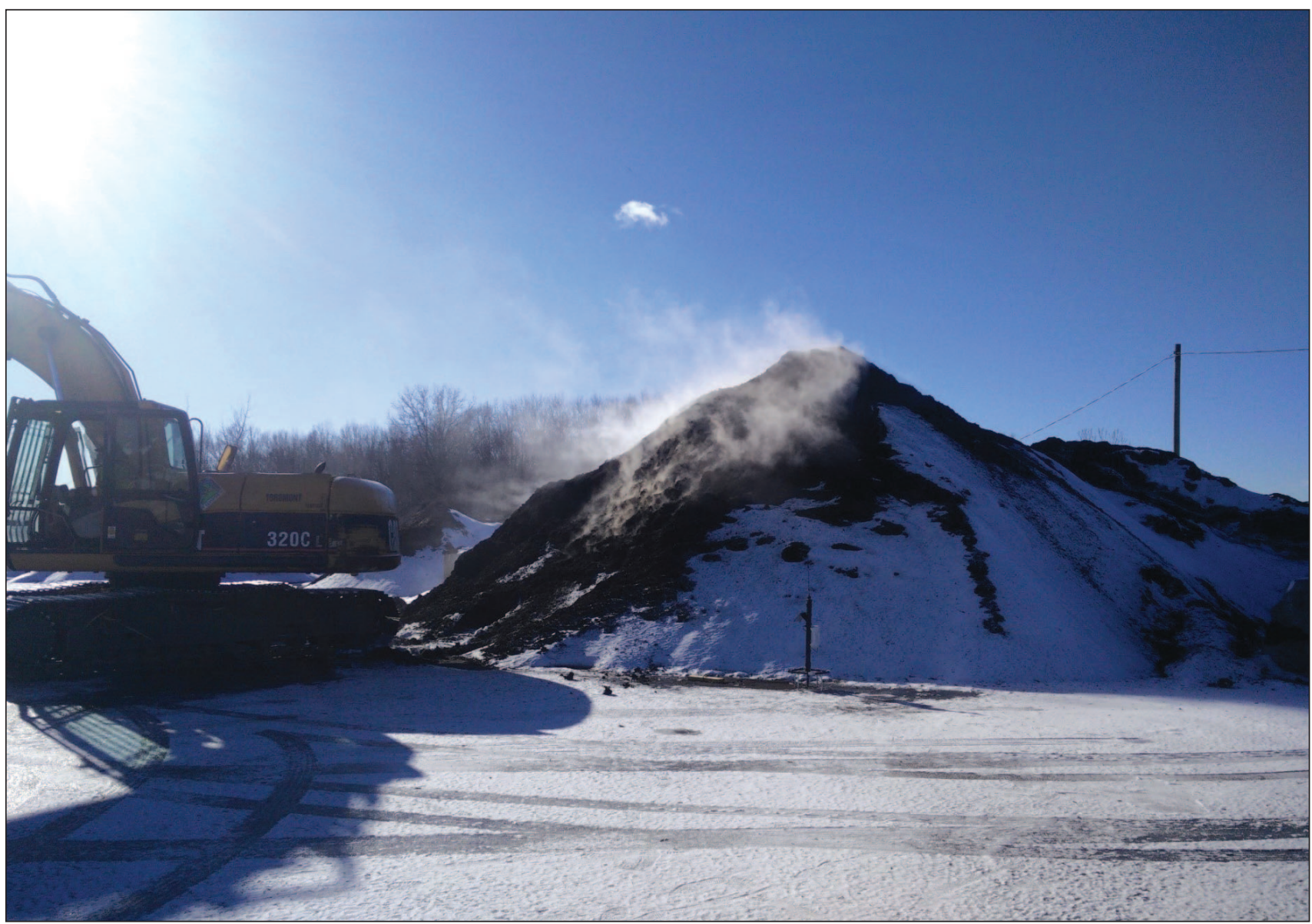

Fig. 1 Pre-treatment techniques for improved feedstock storeability

\section{Issue statement}

Maintaining high quality feedstock storage for sustained bioenergy production continues to be a challenge within the supply chain. While forest sector by-products have the potential to provide a low carbon energy source that can be both economic and environmentally friendly, woody biomass can be a challenging material to transport and store for long periods, in part because it can take different forms with varying characteristics such as moisture content, bulk density, and degradation potential (Krigsten et al. 2019). Researchers from Natural Resources Canada's Canadian Forest Service (CFS) have indicated that during storage, decomposition leads to material and energy losses, and of greater consequence, to self-heating and in extreme cases, fires (Mak et al. 2019). Biomass storage is an essential component in bridging the gap between supply and demand and in facilitating the growth of Canada's bioenergy market.

\section{Research solution}

To encourage the establishment of a bioenergy market and to help ensure a safe and stable fuel source, CFS researchers, along with members of CanmetENERGY, contributed their scientific expertise to the development of a solid biofuels guide based on existing national standards (Keefe et al. 2014). The scope of the Canadian Standard Association's (CSA) guide is wide-ranging with the objective to ensure market confidence for an established woodchip fuel supply chain. This project looks specifically at CFS research that contributed to the CSA guidelines on reducing material and energy loss during transportation and storage. These standards provide clear guidelines and knowledge on fuel attributes, supply, procurement, and storage management practices to reduce material and energy loss, potentially unlocking economic benefits necessary to develop the Canadian bioenergy market.

\section{Results and discussion}

This project explores the potential economic impacts for bioenergy producers of implementing the CSA guidelines that reduce material and energy loss during transportation and storage. Storage and logistics often drive the economics of using woody biomass as a fuel or feedstock for bioenergy applications (Keefe et al. 2014). As such, this report assesses the direct and indirect economic benefits of implementing the CSA guidelines through a cost benefit analysis (CBA), compared to the business as usual scenario in which bioenergy producers currently operate.

This analysis uses data from a 2018 survey of more than 400 primarily commercial and institutional Canadian bioenergy facilities, a substantial sample of the Canadian bioenergy market. These facilities have a combined energy capacity of over 406 thermal megawatts $\left(\mathrm{MW}_{\mathrm{th}}\right)$, the equivalent energy 
required to heat more than 42000 single detached homes. To provide this energy capacity, these facilities consume and store more than 400 thousand tonnes of biomass annually, valued at close to $\$ 28$ million dollars.

\section{Reducing material loss during storage}

Higher levels of decomposition (i.e., dry-matter loss) when storing woodchips amounts to lower available energy output and decreased economic value. Dry-matter loss - the decomposition of material mainly due to microorganism proliferation and succession - is highly correlated to temperature and moisture content. For example, CFS researchers estimate that in poor storage scenarios, dry-matter loss can reach $3 \%$ per month or more. After an average 8-month storage period, a typical pile could lose a quarter of its volume. CFS researchers developed standards for the CSA guidelines that reduce moisture content in storage piles, limiting dry-matter loss. This analysis estimates that when accounting for the use of better storage practices as per the CSA guidelines, a decrease of $1 \%$ per month in dry-matter loss for eight months would result in material savings of over \$2 million for bioenergy producers annually.

\section{Reduced transportation costs}

Transportation costs are a function of the mass of the material transported. Therefore, a reduction in woodchip mass would translate to a reduction in transportation costs for facilities using woody biomass as a fuel. A central objective of logistics management is to reduce the delivered cost of the material. One method the CFS researchers propose is to treat woodchips with natural air-drying. Pre-treatments, such as natural air-drying, reduce the overall moisture content of woody biomass during storage. When it occurs before transportation, the benefits of natural air-drying are extended to a reduction in transportation costs to the storage site. Our economic analysis shows that for every $1 \%$ of biomass feedstock that undergoes natural air-drying prior to transportation (reducing moisture content in storage from $55 \%$ to $35 \%$ (Volpé 2018), bioenergy producers benefit from annual savings of more than $\$ 40000$.

\section{Net energy gain}

The reduction of moisture content via natural air-drying also increases the quality and energy potential of woody biomass feedstock, CFS researchers have estimated that this technique provides a positive net energy gain of 9 to $32 \%$ (compared to original biomass energy content) depending on the conditions (Mak et al. 2019). While this CBA does not directly capture this benefit, these net energy gains are significant for bioenergy facilities. Essentially, natural air-drying requires less energy to dry material than conventional techniques, further increasing the benefits of its use.

For this initial analysis, it is assumed that there are no additional labour costs, training, facility upgrades, or additional equipment because these costs are still largely unknown and cannot be easily estimated by CFS researchers at this time. A more in-depth assessment would require these additional variables. It is therefore assumed that pre-treatment processes such as natural air-drying and proper storage protocols are already set-up and ready to be implemented by bioenergy facilities.

\section{Conclusion}

The results of this report contribute to the integration of economic considerations in policy development for biomass feedstock optimization for the Canadian bioenergy industry. The CFS research that contributed to the CSA guidelines pushes the industry closer to ideal storage practices. Although the costs of implementing these guidelines remain largely unknown, it is clear that by implementing the CSA guidelines, bioenergy producers will benefit from reductions in material and energy loss during transportation and storage. As a result, a $1 \%$ decrease in degradation and $1 \%$ increase in natural air-drying prior to transportation, leads to $\$ 10$ million in savings for the forest sector over a 5-year discounted period.

\section{Next steps}

- The outcomes of this research are national in scope, benefiting bioenergy facilities from British Columbia to Newfoundland and Labrador. As a result, there is significant value in expanding the scope of this initial research. Some possibilities may include:

- Regionally focused case studies to optimise storage practices and pre-treatment techniques to account for Canada's varied seasons and weather;

- Follow-up case studies with facilities who are using the guidelines, to gauge discernable benefits in terms of dry matter loss and energy efficiency;

- Better understanding of where the pre-treatment and storage guidelines are incorporated into the supply chain to maximize efficiency gains;

- Investigation into needed transportation infrastructure. Some facilities are co-located but others may require that feedstock travel up to 300 kilometres to arrive to a storage site; and,

- Broaden the scope of research to include health and safety benefits, environmental benefits, as well as a more comprehensive understanding of associated costs to facilities for incorporating these techniques.

\section{References}

Keefe R., N. Anderson, H. Hogland and K. Muhlenfeld. 2014. Woody biomass logistics [Chapter 14]. In: Karlen, Douglas, ed. Cellulosic Energy Cropping Systems. West Sussex, UK: John Wiley and Sons. p. 251-279.

Krigstin, S., C. Helmeste, H. Jia, K.E. Johnson, S. Wetzel, S. Volpé, W. Faizal and F. Ferrero. 2019. Comparative analysis of bark and woodchip biomass piles for enhancing predictability of self-heating, Fuel 242: 699-709. doi:10.1016/j.fuel.2019.01.056

Mak, J., H. Landry, L. Grieger, J. Agnew, S. Krigstin, C. Helmeste, S. Wetzel, S. Madrali and S. Volpé. 2019. An assessment of ambient and heated forced air drying pre-treatments for enhancing the quality of various forest biomass feedstocks, Front. Energy Res 8: doi:10.3389/fenrg.2020.00007

Natural Resources Canada. 2020. Electricity facts [online]. Available from: https://www.nrcan.gc.ca/science-data/data-analysis/ energy-data-analysis/energy-facts/electricity-facts/20068 [accessed 16 December 2020]

Volpé, S. 2018. Best management practices guide for access to quality forest feedstocks. FPInnovations. SP-534. 